\title{
Postmodernization: A Phase We're Going Through? Management in Social Care
}

\author{
John Lawler and Elizabeth Harlow
}

Dr John Lawler is Lecturer in Public Sector Management, University of Leeds. He previously worked as a local authority social worker, then Teaching Fellow at University of Bradford Management Centre. His research includes management development in social work; management and leadership in public sector organizations; user and caregiver views of services, and organizational change. He has published in each of these areas.

Dr Elizabeth Harlow is a Senior Research Fellow and a member of the Salford Centre for Social Work Research, based at the University of Salford. Prior to this, she worked as a Senior Lecturer at the University of Bradford where she taught child development and child care practice as well as organization and management theory to undergraduate and postgraduate students. Her research interests include: gender, organizations and career; new public sector managerialism; and the changing nature of social work. She has recently published in the journals European Journal of Social Work, Journal of Social Work and Practice. She has co-edited two collections: Management, Social Work and Change (with John Lawler); and Information and Communication Technologies in the Welfare Services (with Stephen Webb).

Correspondence to John Lawler, Management and Leadership Group, Institute for Health Sciences and Public Health Research, University of Leeds, 71-75, Clarendon Road, Leeds LS2 9PL, UK. E-mail: J.A.Lawler@Leeds.ac.uk

\section{Summary}

This paper considers the challenges facing managers of social care services in public sector organizations in the UK. Some theorists might argue that these challenges are the manifestation of a new postmodern era. It is argued here, however, that society is not fully postmodern: indeed modernity continues with some of its features (such as a concern with rationality and reason) heightened and intensified. Social trends associated with this transitional phase of postmodernization have been highlighted in the literature and here they form the framework for discussing social care management today.

Keywords: Social care management; postmodernization 


\section{Introduction}

Social care is characterized by uncertainty, complexity and ambiguity. Whilst this is also the case in other domains, there are aspects of social care that characterize its difference, for example: its particular function and history; the nature of public sector accountability; the contested power relations between professionals and managers; and the relatively recent emphasis on the role of managers in organizing effective service provision. On account of these features, particularly the latter, academics have given increased attention to its management (see, for example, May and Brunsdon, 1999; Coulshed and Mullender, 2001; Butcher, 2002). However, consideration of postmodernism or postmodernization in relation to social care management is relatively sparse. This is surprising as generic management has been exposed to postmodern analyses (Hassard and Parker, 1993; Boje, 1996; Welge and Holtbrugge, 1999; Hancock and Tyler, 2001; Townley, 2002) and there has been much exploration of postmodern concepts in social care, together with analysis and debate regarding their implications for social work practice (McBeath and Webb, 1991; Parton, 1994; Pease, 2002; Hugman, 2003). Given this omission, this paper aims to trace social trends and related developments in social care and identify implications for social care managers. The authors, however, do not accept that society is now postmodern. Instead they argue (following the work of Crook et al., 1992 and O'Brien and Penna, 1998) that we now occupy a phase of postmodernization. This theoretical foundation will be set out in the next section. Before this, though, it is important to note that, although debate over the terms 'social care', 'care management' and 'social work' is recognized (Beresford, 2001; Postle, 2002), the term social care is used here to cover the range of care and protection activities provided by statutory agencies that are delivered by qualified and unqualified workers.

\section{Modernism, postmodernism and postmodernization.}

In modern, post-enlightenment times, development has been founded on the assumption that with more information, a better understanding of our world would develop. This would enable greater control to be assumed and improvements made (for example, in work organization). Indeed, Habermas notes that the enlightenment was founded on:

... ideals of perfection and the notion, inspired by modern science, of the infinite progress of knowledge and an infinite advance towards social and moral betterment (1992, p. 159).

For theorists such as Parton (1994), however, the modern has given way to the postmodern. The certainty of enlightenment thinking has gone and we now inhabit: 
A world which has become disorientated, disturbed and subject to doubt...characterised by the fragmentation of modernity into forms of institutional pluralism marked by variety, difference, contingency, relativism and ambivalence-all of which modernity sought to overcome (Parton, 1994, p.10).

Not everyone is convinced by Parton's argument, however, as Smith and White (1997) demonstrate when, in criticizing Parton's position, they indicate that modernism is alive and well. Nor is Clarke (1996) sympathetic, as shown when he challenges the coherence of the postmodern thesis and questions the evidence for the arrival of a new era. Certainly within the field of welfare, the modernist notion of progress continues: a greater understanding of problems is believed to give rise to more effective solutions. The rationalist thinking that informed management theories in the early part of the last century (as seen in the work of Taylor, Fayol and Weber, for example) continues to have influence today. It can be seen in approaches to do with 'Business Re-engineering', 'Quality' and 'Business Excellence' (Daft, 2000). These approaches in turn impact upon the management of social care (Lawler, 2000): rationalistic management solutions such as benchmarks and performance indicators are to be found in all social care organizations. Nevertheless, although difficult to capture and explain, it is impossible to deny that there are features of life today that are new and unsettling: the pace of change is rapid and we can no longer rely on old certainties. Hence, Crooke etal.'s (1992) argument that we are in a transitional phase between modernism and postmodernism, is convincing. Elements of the postmodern co-exist with the modern. Indeed, during this period of transition, we are witness to an acceleration or intensification of many facets of modernism.

Rather than being superseded, fundamental characteristics of modernism, such as rationality, causality, agency, certainty and sovereign power (Townley 2002), are now emphasized. Within the social and organizational worlds, processes such as detraditionalization, rationalization and differentiation continue (Crook et al., 1992). Detraditionalization refers to the demise of traditional systems and relationships. Their demise, however, does not herald the onset of a new stable order. Instead, change and instability accelerate. From the modernist perspective, life has, paradoxically, become more complex, less easily understood, and much of Parton's description (above) of today's world holds good. O'Brien and Penna (1998) have identified the trends associated with this potential phase of postmodernization. These are: bureaucratic decentralization; the increasing importance of global and local connections; the fragmentation of political culture; and desocietalization. Together, these trends create a complex context in which social care managers must operate. In what follows, the manifestation of these trends in social care is traced, and the new challenges confronting managers are identified. 


\section{Postmodernization and social care}

\section{Bureaucratic decentralization: the dispersal and delegation of responsibilities}

There are two related aspects of decentralization-dispersal, which refers to the outward or horizontal displacement of activities, and delegation, which refers to the shift of authority to those lower down a chain of command. Attention will first be given to the principle of dispersal. From the 1940s, central government had a crucial role in providing welfare services. This bureaucratic arrangement was increasingly under critical attack from a range of political and ideological persuasions (see for example, Lowe, 1994): it was criticized for being unable to meet the varied and changing needs of the population as well as for being expensive. The consequence was the gradual dismantling of the 'welfare state': responsibility for the provision of welfare has been dispersed away from the public sector, in particular local authorities, to a range of private or charitable organizations. Compulsory Competitive Tendering (CCT), introduced by the 1988 Local Government Act, required local authorities to consider alternative providers for specified local services. Social services were, however, exempted. Informed by public choice theory, this strategy aimed to make service provision more economical, efficient and effective.

Whilst CCT provided an important policy context, it was the NHS and Community Care Act (1990) that aimed to disperse the responsibility for adult social care. Local Authorities were no longer expected to offer services for adults directly, but instead purchase them on behalf of the local population from the aforementioned range of providers (see Rao, 1996). Although this legislation applied specifically to adult care, the principles were soon applied across the board. Local Authorities were required to consider outsourcing welfare services under the terms of the government's policy of Best Value-the Labour Party's alternative to CCT. Introduced in 2000 as part of its modernization agenda (see DETR, 1998), the government intended that the criteria of quality as well as cost would guide purchasing decisions. Dispersing the responsibility for services across a range of providers has required an emphasis on the development of structural partnerships. The 1999 Health Act Partnership Arrangements enabled health and local authorities jointly to fund provision and delegate functions. The Health and Social Care Act (2001) went a step further by facilitating the creation of Care Trusts. Care Trusts are built upon established partnership arrangements but enable the delivery of health and social services by means of a single organization and management structure. However, National Health Service (NHS) and local authority functions are not transferred, they are delegated. Although not determined, it was assumed by the Department of Health that Care Trusts would focus on services for adults (www.doh.gov.uk/caretrusts/infobackground.htm accessed April 14, 2003). Four Trusts were established in April 2002 (Bradford; Camden and Islington; 
Manchester; and Northumberland) and many others are in the process of being established (Revans, 2003).

Children's Trusts were initiated prior to the Green Paper 'Every Child Matters' (DFES, 2003), but their creation has been reinforced by proposals in this document. They also aim to reduce duplication of effort and wastefulness as well as improve the quality of services made available. The efforts of those such as Health Visitors, School Nurses, Midwives, Social Workers, Teachers, Youth Workers and Connexions staff may be harnessed in an attempt to improve service delivery. The exact design of Children's Trusts is to be decided at local level: the whole gamut of resources for children aged between 0 and 19 may be 'joined up' or a Trust may restrict its focus to certain elements of provision for children. Multi-disciplinary teams are an aspect of this new 'joined-up' approach to the delivery of social care. The benefits are said to include not only the financial savings indicated above, but also: the pooling of skills and information; continuity of care; agreement on responsibility and accountability; and improved coordination in the planning and delivery of services (Payne, 2000).

Over the last 20 years, the terrain of social care provision has been transformed. Managers are now having to commission and purchase services from the 'care market', devise contracts, integrate service provision through the development of new partnerships as well as manage multi-disciplinary teams. In addition to keeping down costs, they have to maintain standards of quality in accordance with government requirements. The government controls quality by means of performance criteria, inspection and audit (Paton, 2003). The opinions of service-users have also been added to what Dean (1997) calls the 'technologies of performance'. By such measures, the government controls the managers and, in order for the managers to control the staff (including the semi-professionals), the role of managers has been enhanced in terms of authority and status. Managers have become the super-heroes of the public sector (Newman, 1994) and management the new meta-narrative.

Whilst retaining control, the government has not only dispersed, but also delegated responsibility for the provision of social care. In particular, managerial responsibilities have been delegated to practitioners through the hierarchical chain of command. Social workers, for example, now have to appreciate and work to specified budgets as well as become implicated in the purchasing and contracting of services. This is seen most clearly in adult care where practitioners are now known as care managers. This new role does not bring enhanced autonomy. On the contrary, critics have argued that a reduction in autonomy has occurred as practitioners have become co-opted into the government's agenda (Dominelli, 1996) and subjected to micro-management (Harris, 1998, 2003; see also Lymbery, 1998). Although the status of practitioners in social care has never been high, and social workers, for example, are known as semiprofessionals as opposed to professionals (see Aldridge, 1996), it could be argued that the power relations between professionals and managers, identified 
above as a particular characteristic of social care, have been reconfigured by the process of postmodernization.

\section{Global and local connections}

Never before has the relationship between the local and the global been so much in focus. Rapid international travel together with new information and communications technologies overcome time and geographical distance to connect people in unprecedented ways. The implications can be multi-faceted, direct or indirect: for example, social care managers in one particular locality of the UK are working to financial budgets that are influenced by international developments. These budgets have been limited by national fiscal policies, which in turn have been affected by labour costs in the developing world, and the impact of global economic competition (Hughes, 2000). Similarly, legislation passed by the European Union in Brussels contributes to the shaping of social care services in UK communities. Electronic communications systems have the potential to exacerbate social problems or create new ones. This can be seen in the development of international crime, particularly in relation to the production and supply of drugs. In the past two decades, criminal organizations have increasingly set up their operations transnationally, taking advantage of economic globalization and new communication and transport technologies. Their strategy is to base their management and production functions in low-risk areas, where they have relative control of the institutional environment, while targeting as preferential markets those areas with the most affluent demand, so that higher prices can be charged (Castells, 2000, p. 171).

The ready availability of hard drugs in the UK contributes to increased usage and attendant difficulties. Whilst hard drugs may constitute only one form of substance abuse, they are nevertheless relevant to the management and practice of social care. Not only might services be offered to drug users themselves but, in addition, services delivered to families have to address the complications of drug usage when addicted parents struggle to nurture and protect their children adequately (see Cleaver et al., 1999). Drugs are also seen as the means by which older men 'groom young women for sexual exploitation and prostitution' (Heal, 2004, p. 32). Electronic communication is also associated with sexual exploitation. Pornographic pictures and films can be generated and circulated globally by means of the Internet. Fears have been expressed that the availability of child pornography via the Internet might lead to an increase in the abuse of children in the UK (Relph and Webb, 2003) or that child abusers in the UK will use the Internet to circulate images of their victims. Hence, new global and local connections lead to new challenges for the managers of agencies charged with the responsibility of protecting the young.

Local and global connections might also contribute to solutions in social care as well as challenges. Social care websites can provide information and 
encourage contributions on topical issues. Specialist Internet newsgroups could become an apposite medium for the sharing of best practice. By means of ICTs, managers involved in the provision of social care can, irrespective of geographical distance, communicate about their work, and in so doing, create new virtual communities-'cyburgs' as Bainbridge (1995 cited in Giffords, 1998) suggests.

\section{The fragmentation of political culture}

According to the postmodernization thesis, party alliances and political allegiances have given way to 'more fluid and informal networks of action' (O'Brien and Penna, 1998, p. 194). In the past, humanist principles and the influence of the Fabians meant that there was a commitment to the welfare state as a means of benefiting the working class. Over recent times, both humanism and Fabianism have declined in significance (Powell, 2001). The welfare state itself has been subject to critique, and the notion of class as the basis for challenging inequality has been attacked. Indeed, according to Waters (1997), we now live in a post-class society. In consequence, efforts to improve welfare provision coalesce around changing foci. During the 1980s and early 1990s, the politics of identity meant that managers were encouraged to consider service provision in the light of the differing needs: for example, uniformity of provision meant inequality as opposed to equality, as the specific needs of black people would go ignored (see Ely and Denney, 1987; Ahmad, 1990; Patel, 1990). Today, in the face of centrally driven performance management, aggregated targets are likely to receive greater attention than diverse requirements. Based on consumerist principles, the impetus for service improvement might be seen to come from those who use the services. Choice over which service to use would require managers to compete for business, and standards would be driven up. In practice, however, service users may not find a range of services from which to choose. Alternatively, customers might be understood as stakeholders, and managers might be expected to devise systems that will allow for their participation in decision making at all levels. The application of consumerist principles to the design and delivery of social care, however, is not always easy. Which consumers should be consulted-past, present or future consumers? Is the consumer the direct recipient of the service, such as an elderly person, or the indirect recipient, such as the informal carer of the elderly person? Also, what about the views of the tax payers who provide the funds for the services? (Harlow, 2000, p. 86 drawing on the work of Dahlberg et al., 1999).

The idea of social care users as customers assumes a simple transactional relationship which does not always apply: the consumption of social care may be uninformed, involuntary or even the result of coercion. In consequence, challenges arise for social care managers who have to introduce systems for securing customers' views as a means of improving service provision. 


\section{Desocietalization}

In the past, 'society' was understood in terms of the nation state: put another way, national frontiers constituted the boundaries of a given society (O'Brien and Penna, 1998). Increasingly, however, boundaries are being challenged and reconfigured:

The emergence of ethnic, religious and nationalist aspirations and tensions has generated considerable instability within many nation states, resulting in the disintegration and reconstitution of many of them (Khan, 2000, p. 117).

Following the cold war, conflicts have arisen in Afghanistan, Yugoslavia has disintegrated, and violent tensions have arisen in many African states. Demand for the reconfiguration of boundaries may come from those whose ethnic identities and religious commitments do not comply with national frontiers, as in the UK, for example. Matters may be exacerbated, however, when global economic developments undermine fragile social systems and political disruption leads to unrest (Kahn, 2000 drawing on the work of Zolberg et al., 1989). Such events can lead to the displacement of populations. According to the High Commissioner for Refugees (UNHCR), in 1977, the global refugee population was estimated to be 2.8 million; 20 years later, the figure increased to 12 million (UNHCR, 1998). This latter figure, however, excludes just over 10 million asylum seekers and displaced persons, who are counted under a separate category as 'populations of concern' (UNHCR, 1998 cited in Khan, 2000, pp. 116-117).

In general, migratory patterns are changing, partly as a result of such developments, but also because modern technologies (satellite television, fax, mobile phones and the Internet) widely distribute information on potential opportunities elsewhere across the globe (Khan, 2000) and modern day transport allows for faster, safer travel across greater distances. In consequence of the above, the number of people seeking asylum in the UK has increased in the past two decades: in 1979, there were only 1563 asylum applications whilst in 1998 there were 58,000 (Home Office, 1999 cited in Khan, 2000). The UK government, mindful of resources, is attempting to reduce the number of applications as well as limit welfare entitlement by means of legislation such as the Nationality, Immigration and Asylum Act 2002. This has implications for social care managers as local government has to respond to the need that the national government is failing to meet (Khan, 2000). Evidence given in the report of Lord Laming (2003) suggests that in some parts of London, the majority of referrals to intake teams are made by vulnerable individuals travelling from abroad. Adult asylum seekers may be experiencing mental ill-health (Sale 2003), dependent children may require assistance, but social services departments also have to respond to the needs of unaccompanied children (see Philpot, 2003; Ritchie, 2003). The specific personal problems, as well as the linguistic and cultural heterogeneity of this group of service users, may mean that workers 
are frequently unprepared and untrained to meet the challenges presented. To add further complexity, national law and policy is overlain by supra-national human rights legislation (see Robins 2003).

Population flows might also remedy some difficulties encountered by the managers of social care. There is indication that the high number of social work vacancies is being addressed by the recruitment of staff from countries such as Australia, New Zealand and South Africa (Taylor, 2000). It is likely that these recruits will, like some of the aforementioned populations, use electronic communication systems and travel to retain links with their families and communities of origin. This creates networks and attachments across the globe that means 'homeland' might sometimes be a problematic term.

\section{Discussion and conclusion}

The decentralization of responsibility for social care has changed the role and practice of managers and reconfigured their relationship with practitioners. Improvements in welfare can no longer be understood simply in terms of humanist principles and inequality between the classes. Instead, managerial solutions and consumer choice are the drivers for the improvement of services. The 'shrinking globe' means that activities across the world impact upon the provision of welfare in the UK, not only in terms of economic policies and resources, but also in terms of population flows. These population flows create demands, offer solutions and lead to international attachments that, according to the postmodernization thesis, challenge the meaning of 'society'.

Whilst many of these developments arise from the intensification of modernist trends, the implications demand responses from managers that go beyond the universal, rational and rigid. The development of ever more sophisticated eligibility criteria or complex managerial solutions will not overcome the speed and breadth of contextual change, or the contradictions and tensions that are inherent to the provision of social care. The acknowledgement of tension and ambiguity, together with flexible innovation, may be essential components of any response. Accepting the postmodernization thesis may require managers to eschew 'once and for all' solutions: the changing context requires changing responses. In keeping with this principle, much has been made of lifelong learning (see Frost, 2001) and the learning organization (see Pedler et al., 1991; Senge, 1999). Put simply, the learning organization is one that can adapt to meet the challenges of a constantly changing environment. Training courses for the benefit of individuals are no longer adequate. Organizational managers need to develop a culture where learning, and sharing what is learnt, works to maintain the continuous improvement in services. Learning, however, needs to go beyond national boundaries. Writers such as Klein (1993) and Midgley (1997) suggest that a review of welfare systems and management across different countries would be helpful. The focus of comparison would be the learning capacity of different systems and the way in which contradictions and tensions 
are addressed. Whilst the concept of the learning organization has some relevance to social care, there is no suggestion that progress will inevitably be achieved by its application. The concept does allow for constant change, the importance of the global environment and complexity of providing social care. Nevertheless, its private sector origins may mean it should be applied with critical caution. Disappointing though it may be, there is no panacea for the problems of postmodernization.

Accepted: October 2004

\section{References}

Ahmad, B. (1990) Black Perspectives in Social Work, Birmingham, Venture Press.

Aldridge, M. (1996) 'Dragged to market: being a professional in the postmodern world', British Journal of Social Work, 26 (2), pp. 177-94.

Bainbridge, W. S. (1995) 'Sociology on the world wide web', Social Science Computer Review, 13, pp. 508-23.

Beresford, P. (2001) 'Service users', British Journal of Social Work, 31 (4), pp. 629-30.

Boje, D. M. (ed.) (1996) Postmodern Management and Organization Theory, New York, Sage.

Butcher, T. (2002) Delivering Welfare Services: Public Policy and Management, Buckingham, Open University Press.

Castells, M. (2000) The Information Age: Economy, Society and Culture. Volume I. The Rise of the Network Society 2nd edn, Oxford, Blackwell.

Clarke, J. (1996) 'After social work?' in Parton, N. (ed.), Social Theory, Social Change and Social Work, London, Routledge.

Cleaver, H., Unell, I. and Aldgate, J. (1999) Children's Needs-Parenting Capacity: The Impact of Parental Mental Illness, Problem Alcohol and Drug Use, and Domestic Violence on Children's Development, London, The Stationery Office.

Coulshed, V. and Mullender, A. (2001) Management in Social Work, Basingstoke, Palgrave.

Crook, S., Pakulski, J. and Waters, M. (1992) Postmodernization: Change in Advanced Society, London, Sage.

Daft, R.L. (2000) Management, London, Dryden Press.

Dahlberg, G., Moss, P. and Pence, A. (1999) Beyond Childhood in Early Childhood Education and Care: Postmodern Perspectives, London, Falmer Press.

Dean, M (1997) 'Sociology after society', in Owen, D. (ed.), Sociology After Postmodernism, London, Sage.

DETR (Department of the Environment, Transport and Regions) (1998) Modernising Local Government: Improving Services Through Best Value, London, The Stationery Office.

DFES (Department for Education and Skills) (2003) Every Child Matters, Nottingham, DFES Publications.

Dominelli, L. (1996) 'De-professionalizing social work: anti-oppressive practice, competencies and postmodernism', British Journal of Social Work, 26 (2), pp. 153-75.

Ely, P. and Denney, D. (1987) Social Work in a Multi-racial Society, Aldershot, Ashgate.

Frost, N. (2001) 'Professionalism, change and the politics of lifelong learning', Studies in Continuing Education, 23 (1), pp. 5-17. 
Giffords, E. D. (1998) 'Social work on the Internet: an introduction', Social Work, 43 (3), pp. 243-51.

Habermas, J. (1992) 'Modernity: an unfinished project?' in Jencks, C. (ed.), The PostModern Reader, London, Academy Editions.

Hancock, P. and Tyler, M.J. (2001) Work, Postmodernism and Organization: A Critical Introduction, New York, Sage.

Harlow, E. (2000) 'New managerialism and social work: changing women's work', in Harlow, E. and Lawler, J. (eds), Management, Social Work and Change, Aldershot, Ashgate.

Harris, J. (1998) 'Scientific management, bureau-professionalism, new managerialism: the labour process of state social work', British Journal of Social Work, 28 (6), pp. 839-62.

Harris, J. (2003) The Social Work Business, London, Routledge.

Hassard, J. and Parker, M. (eds), (1993) Postmodernism and Organization, London, Sage.

Heal, A. (2004) 'The sex trap', Community Care, 10th-16th June, pp. 32-33.

Hughes, L. (2000) 'Crossing, building, breaking the boundaries: social work in a global context', in Harlow, E. and Lawler, J. (eds), Social Work, Management and Change, Aldershot, Ashgate.

Hugman, R. (2003) 'Professional values and ethics in social work: reconsidering postmodernism?', British Journal of Social Work, 33 (8), pp. 1025-41.

Khan, P. (2000) 'Asylum-seekers in the UK: implications for social service involvement', Social Work and Social Sciences Review, 8 (2), pp. 116-129.

Klein, R. (1993) 'O' Goffe's tale: or what can we learn from the success of capitalist welfare states', in Jones, C. (ed.), New Perspectives on the Welfare State in Europe, London, Routledge.

Laming, H. (2003) The Victoria Climbié Inquiry. Report of an Inquiry by Lord Laming, London, The Stationery Office.

Lawler, J. (2000) 'The rise of managerialism in social work', in Harlow, E. and Lawler, J. (eds), Management, Social Work and Change, Aldershot, Ashgate.

Lowe, R. (1994) 'Lessons from the past: the rise and fall of the classic welfare state in Britain, 1945-76', in Oakley, A. and Williams, A. S. (eds), The Politics of the Welfare State, London, UCL Press.

Lymbery, M. (1998) 'Care management and professional autonomy: the impact of community care legislation on social work with older people', British Journal of Social Work, 28 (6), pp. 863-78.

May, M. and Brunsdon, E. (1999) 'Social services and community care', in Horton, S. and Farnham, D. (eds), Public Management in Britain, Houndsmill, Macmillan.

McBeath, G. and Webb, S. (1991) 'Social work, modernity and postmodernity', Sociological Review, 39 (4), pp. 745-62.

Midgley, J. (1997) Social Welfare in a Global Context, Thousand Oaks, CA, Sage.

Newman, J. (1994) 'The limits of management: gender and the politics of change', in Clarke, J., Cochrane, A. and McLaughlin, E. (eds), Managing Social Policy, London, Sage.

O'Brien, M. and Penna, S. (1998), Theorising Welfare: Enlightenment and Modern Society, London, Sage.

Parton, N. (1994) 'Problematics of government: (post) modernity and social work', British Journal of Social Work, 24 (1), pp. 9-32.

Patel, N. (1990) A 'Race' Against Time? Social Services Provision to Black Elders, London, Runnymede Trust.

Paton, R. (2003) Managing and Measuring Social Enterprises, London, Sage. 
Payne, M. (2000) Teamwork in Multiprofessional Care, Basingstoke, Macmillan.

Pease, B. (2002) 'Rethinking empowerment: a postmodern reappraisal for emancipatory practice', British Journal of Social Work, 32 (2), pp. 135-47.

Pedler, M., Burgoyne, J. and Boydell, T. (1991) The Learning Company: A Strategy For Sustainable Development, London, McGraw Hill.

Philpot, T. (2003) 'Bad company?', Community Care, 6th-12th November, p. 34.

Postle, K. (2002) 'Working between "the idea and the reality": ambiguities and tensions within the care managers' work', British Journal of Social Work, 32 (3), pp. 335-35.

Powell, F. (2001) The Politics of Social Work, London, Sage.

Rao, N. (1996) Towards Welfare Pluralism: Public Services in Times of Change, Aldershot, Ashgate.

Relph, B. and Webb, S. (2003) 'Internet child abuse' in Harlow, E. and Webb, S. (eds), Information and Communication Technologies in the Welfare Services, London, Jessica Kingsley.

Revans, L. (2003) 'Pioneers together', Community Care, 3rd-9th April, pp. 28-31.

Ritchie, C. (2003) 'Children cut adrift', Community Care, 2nd-8th October, pp. 36-7.

Robins, J. (2003) 'Crunch time for asylum', Community Care, 20th-26th March, pp. 34-5.

Sale, A. U. (2003) 'It's the survivors who thrive', Community Care, 30th October5th November, pp. 24-5.

Senge, PM. (1999) The Fifth Discipline: The Art and Practice of the Learning Organization, London, Random House Business Books.

Smith, C. and White, S. (1997) 'Parton, Howe and post-modernity: a critical comment on mistaken identity', British Journal of Social Work, 27 (2), pp. 275-97.

Taylor, M. (2000) 'Follow the standards', Community Care, 17th-23rd August, p. 12.

Townley, B. (2002) 'Managing with modernity', Organization, 9 (4), pp. 549-73.

UNHCR (United Nation High Commissioner for Refugees) (1998) Refugee and Asylum Statistics, Geneva, UNHCR.

Waters, M. (1997) 'Inequality after class', in Owen, D. (ed.), Sociology After Postmodernism, London, Sage.

Welge, M.K. and Holtbrügge, D. (1999) 'International management under postmodern conditions', Management International Review, 39 (4), pp. 305-22.

Zolberg, A. Suhrke, A. and Aguayo, A. (1989) Escape from Violence. Conflict and the Refugee Crisis in the Developing World, New York, Oxford University Press. 